КУШНІР Г.А., ПРИХОДЬКО Ю.П.

\title{
КРИМІНАЛІСТИЧНА ХАРАКТЕРИСТИКА МЕХАНІЗМУ УТВОРЕННЯ СЛІДІВ НА ГІЛЬЗАХ, ВИСТРІЛЯНИХ ІЗ САМОРОБНОЇ ВОГНЕПАЛЬНОЇ ЗБРОЇ
}

\begin{abstract}
У статті викладено механізм утворення слідів на гільзах, стріляних в різних зразках саморобної вогнепальної зброї, а також детально описані сліди від різних деталей і вузлів саморобної вогнепальної зброї, що утворюються на гільзах в результаті заряджання зброї і здійснення з неї пострілу, вивчення яких може сприяти визначенню конструктивних особливостей самої зброї. Наголошено, що неодмінною умовою пострілу із застосуванням саморобної (як і будь-якої іншої казнозарядної) вогнепальної зброї $є$ можливість введення патрона в патронник. 3'ясовано, що під час визначення конструктивних особливостей зброї, крім зазначених слідів, важливе значення мають і сліди, залишені при контакті гільзи з іншими деталями і вузлами, що вказують на саморобний спосіб виготовлення зброї. Визначено, що на незначне перевищення діаметра гільзи вказують траси, які залишаються на циліндричній частині корпуса паралельно іiї осі. Такі сліди відображаються під час досилання патрона в патронник або видалення гільзи із застосуванням значних зусиль. Аналогічні сліди залишаються під час видалення гільзи у разі використання патрону із значним пороховим зарядом, коли ії корпус в процесі пострілу щільно обжимає внутрішню поверхню патронника, що має різні нерівності (рисунок 6), або при контакті з краями казенного зрізу ствола, що має (внаслідок грубої обробки) гострі виступи (задири). Наведено, що сліди на денцях гільз можуть залишитися також від рамок саморобних револьверів. Вертикальний слід «подряпина» утворюється під час застосування однозарядних пістолетів 3 переломним стволом, у якого бойок виступає за межі поверхні чашки затвора тощо. Зроблено висновок, що роздуття дулець гільз до циліндричної форми, за якої торець має багатокутну форму, і на поверхні утворюються слабо виражені сліди від полів нарізів, свідчать про те, що патрони використовувалися в зброї з однаковим за діаметром патронником, у якого довжина менше, ніж у гільзи. Під час пострілу з такої зброї на схилі корпусу гільзи залишається слід у вигляді кільця, залишеного кромкою кулевого входу каналу ствола. За таким слідом можна визначити довжину патронника зброї, із якої стріляли.
\end{abstract}

Ключові слова: саморобна вогнепальна зброя, патрон, гільза, патронник, калібр зброї, чашка затвора, подавач, слід бійка ударника, порохові гази.

The article describes the mechanism for the formation of marks on shells shot in various samples of improvised firearms, and also describes in detail the marks from various parts and components of improvised firearms generated on shells as a result of loading a gun and firing from it, the study of which can help to determine the constructive features of the weapon itself. It is emphasized that the indispensable condition of a shot with the use of improvised (as well as any other casinos) firearms is the possibility of inserting a cartridge into the chamber. It is found that in determining the design features of the weapon, in addition to these traces, the traces left by the contact of the sleeve with other parts and assemblies indicating an improvised way of making the weapon are also important. It is determined that the traces remaining on the cylindrical part of the housing, parallel to its axis, indicate a slight excess of the diameter of the sleeve. Such traces are

(C) КУШНІР Г.А. - кандидат юридичних наук, доцент, доцент кафедри кримінального права, процесу та криміналістики юридичного факультету (Академія праці, соціальних відносин і туризму)

( С ПРИХОДЬКО Ю.П. - кандидат юридичних наук, доцент кафедри криміналістичного забезпечення та судових експертиз (Навчально-науковий інститут № 2 Національної академії внутрішніх справ) 
displayed when sending the cartridge to the chamber or removing the cartridge using considerable effort. Similar traces remain when the sleeve is removed in cases of use of a cartridge with a high powder charge, when its body tightly compresses the inner surface of the chamber having different irregularities (shot 6) or in contact with the edges of the breech cut having (due to rough processing) ) sharp performances (badasses). It is stated that traces on the bottom of the sleeves may also remain from the frame of improvised revolvers. The vertical trace of a "scratch" is formed when using single-shot pistols with a tipping barrel, in which the striker protrudes beyond the surface of the shutter cup, etc. It is concluded that the inflating of the tubular sleeve to a cylindrical shape, in which the end has a polygonal shape, and on the surface formed slightly pronounced marks from the rifling fields, indicate that the cartridges were used in weapons, with the same diameter of the chamber, whose length is smaller, than the sleeve. When fired with such a weapon, the slope of the body of the sleeve remains trace in the form of a ring left by the edge of the bullet entrance of the barrel channel. In this way you can determine the length of the chamber of the weapon from which it was fired.

Key words: home-made firearms, cartridge, cartridge case, chamber, caliber of weapons, bolt cup, rammer, trace of the striker, powder gases.

Вступ. Останнім часом в Україні спостерігається зростання кримінальних правопорушень 3 використанням саморобної та переробленої вогнепальної зброї. До такої зброї можна віднести газові пістолети та револьвери, пневматичні гвинтівки, які пристосовані для стрільби стандартними боєприпасами. Зазначена проблематика не $\epsilon$ новою для правоохоронних структур взагалі та експертів практиків зокрема.

Стан дослідження. Протягом останніх років вчені у своїх працях все частіше розглядають особливості дослідження саморобної вогнепальної зброї та слідів ії застосування. У різні періоди окремі аспекти криміналістичного дослідження вогнепальної зброї досліджували В.В. Арешонков, В.Ф. Гущин, М.М. Зюскін, А.В. Кофанов, В.К. Лисиченко, Б.М. Комаринець, Ю.В. Мішин, Л.Ф. Саврань, І.О. Сапожніков, Є.І. Сташенко, Є.М. Тихонов, О.І. Устинов, В.Ф. Черваков, Б.І. Шевченко. Однак, на наш погляд, бракує грунтовних праць, де розглядалися б особливості криміналістичного дослідження слідів на гільзах від частин саморобної та переробленої вогнепальної зброї, що й зумовлює актуальність дослідження обраної теми.

Постановка завдання. Метою статті є криміналістична характеристика механізму утворення слідів на гільзах, вистріляних із саморобної вогнепальної зброї.

Результати дослідження. Практика показує, що в ході проведення стрільби з різних видів саморобної вогнепальної зброї на гільзах утворюється комплекс слідів, характерних такому виду зброї, які сприяють встановленню його конструктивних особливостей. Залежно від виду, системи або моделі зброї кількість слідів на стріляних гільзах може бути різною. Найбільша кількість слідів утворюється на гільзах, стріляних з автоматичної зброї. Їх можна розділити на три самостійні групи:

- сліди, подібні слідам стандартної вогнепальної зброї, вогнепальної зброї обмеженого ураження, газової або сигнальної зброї, оскільки зброя, що перебуває в розшуку, виготовлялася на їх базі;

- сліди, що являють собою їх сукупність, характерну як для стандартної, так і для саморобної зброї, тобто зброя, що перебуває в розшуку, має комплекс деталей заводського і саморобного виготовлення;

- сліди на гільзах, що подібні до слідів саморобної вогнепальної зброї [1, с. 97-99].

Неодмінною умовою пострілу із застосуванням саморобної (як і будь-якої іншої казнозарядної) вогнепальної зброї є можливість введення патрона в патронник. Якщо розміри гільзи патрона значно менші за розміри патронника, то без відповідного їх закріплення за допомогою тимчасових (одноразових) або постійних пристосувань можливість пострілу буде обмежена. Це не означає, що розміри гільзи патрона обов'язково повинні відповідати розмірам патронника 3 повним збігом їх по довжині та діаметру. За наявності на корпусі гільзи продовгуватого за формою здуття, тріщин, розривів (рисунок1. «а», «б»), в сукупності зі слідами від бойка і патронного утику (при цьому будуть відсутні інші сліди від деталей зброї, в тому числі патронника), можна зробити висновок, що гільза вистріляна зі зброї, що має патронник значно більших розмірів, ніж розміри гільзи. 
В цьому випадку для утримання гільзи в патроннику її могли обгорнути в своєрідну «сорочку» 3 паперу (рисунок 2), тканини, ізоляційної стрічки або іншого матеріалу, який не охоплював її повністю, а являв собою згорнуту у вигляді трубки скобу (одноразові пристосування).

Такі пристосування після пострілу зазвичай більше не використовуються. Для здійснення пострілу із саморобної зброї з великими розмірами патронника можуть також використовуватися постійні пристосування, які стаціонарно закріплюються в каналі ствола (ствол-вставка), або змінні, призначені для конкретного виду патронів (металеві «сорочки»), але, на відміну від одноразових, вони можуть використовуватися кілька разів. Більш точно відображають неповний збіг розмірів гільзи і патронника зброї сліди у вигляді здуття і розривів (тріщин).

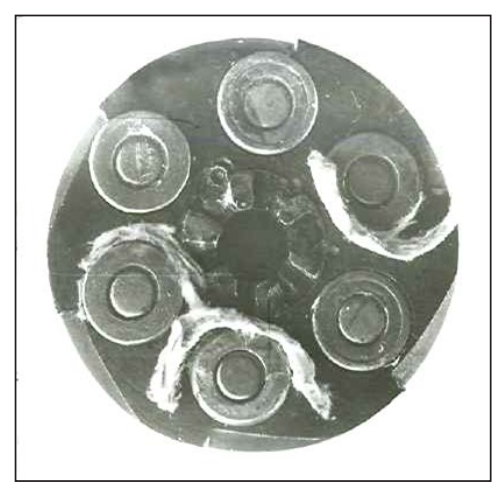

\footnotetext{
Рис. 2. Барабан саморобного револьвера 3 патронами, обгорнутими папером для забезпечення щільного контакту 3 поверхнею камор барабана
}

Відомо, що деякі виступи (на 3 мм) гільзи за казенний зріз патронника не $\epsilon$ перешкодою для здійснення пострілу. Такі виступи бувають у разі незначного перевищення довжини патрона щодо довжини патронника саморобної вогнепальної зброї, яке не дозволяє помістити патрон в магазин, але водночас не заважає його ввести безпосередньо рукою в патронник ствола.

Роздуття дулець гільз до циліндричної форми, за якої торець має багатокутну форму і на поверхні утворюються слабо виражені сліди від полів нарізів, свідчить про те, що патрони використовувалися в зброї з однаковим за діаметром патронником, у якого довжина менше, ніж у гільзи. Під час пострілу з такої зброї на схилі корпусу гільзи залишається слід у вигляді кільця, залише-

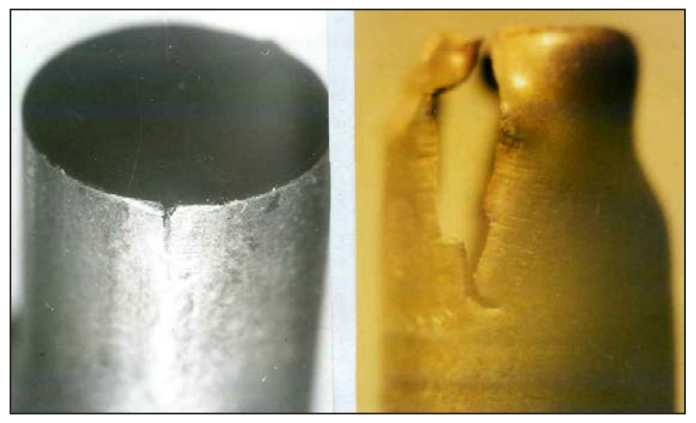

a)

б)

Рис. 1. Сліди на гільзах, стріляних з саморобної вогнепальної зброї: а) тріщина

на дульці гільзи від патрона 9х18 мм; б) розрив корпусу гільзи від патрона 5,45x39 мм

Під час вивчення гільз від патронів до ПМ, ТТ і АК-74, стріляних з різних моделей саморобної вогнепальної зброї з перевищеним розміром патронника, В ревлено, що всі гільзи мають характерні роздуття лу) конструктивні особливості частин зброї, шо контактують 3 нею, відображаються на її корпусі. Діаметри і форма роздутостей корпусів гільз і їх дулець зумовлені розміром і формою патронника застосовуваної зброї.

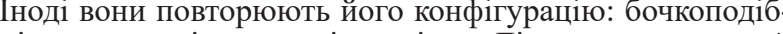
ність, конусність, ступінчастість. Діаметр роздутостей дулець гільз приблизно характеризує калібр зброї, 3 лого вони стріляні (під час застосування зброї більшо作 дулець). Довжина гільз за рахунок роздуття може скоротитися. На корпусах гільз до пістолета Тульський Тока(ТT) в слідах керніння, особливо в найбільш тонких i жорстких місцях, спостерігаються розриви (тріщини) (рисунок 3).

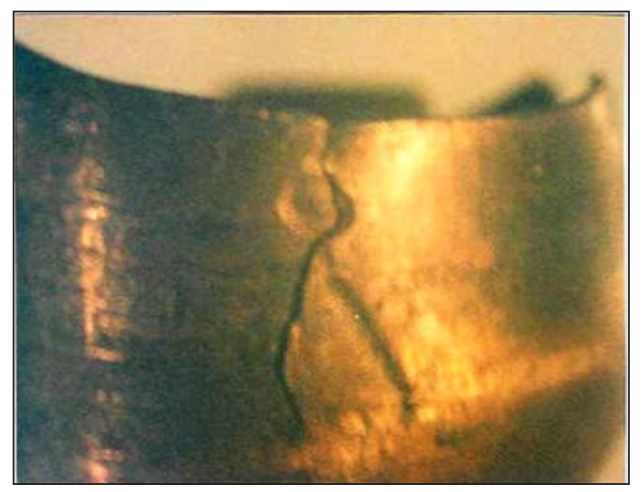

Рис. 3. Тріщина на корпусі гільзи від патрона до пістолета ТT, яка утворилася під час пострілу із саморобної вогнепальної зброї 


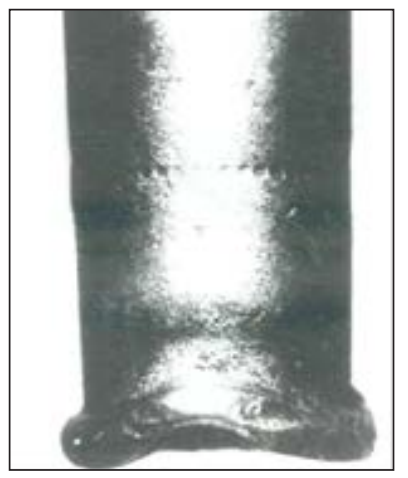

Рис. 4. Роздуття корпусу гільзи, утворене за неповного поміщення патрона в патронник

ного кромкою кулевого входу каналу ствола. За таким слідом можна визначити довжину патронника зброї, із якої її було вистріляно.

Якщо здуття або навіть розрив спостерігаються на корпусі з боку фланця біля кільцевої проточки або денця гільзи (рисунок 4), це свідчить про те, що патрон повністю поміщався в патроннику і суттєво виступав за край його казенного зрізу. Здуття корпусу може бути як по всьому колу гільзи, так і фрагментарно - з одного боку, але в обох випадках за межами здуття можна точно визначити довжину патронника використаної зброї.

Гільзи, стріляні в саморобній вогнепальній зброї (з більшою різницею діаметрів під час видалення їх із патронника), мають перекіс і можуть затискатися між патронним утиком затвора і казенною частиною ствола [2, с. 81-85]. В результаті на дульці гільз спостерігаються характерні вм'ятини, а на краях денець гільз відображаються сліди ребра чашки затвора (рисунок 5) і частково - подавача.

На незначне перевищення діаметра гільзи вказують траси, які залишаються на циліндричній частині корпуса паралельно іiі осі. Такі сліди відображаються під час досилання патрона в патронник або видалення гільзи із застосуванням значних зусиль. Аналогічні сліди залишаються під час видалення гільзи у випадках використання патрону із значним пороховим зарядом, коли іiі корпус в процесі пострілу щільно обжимає внутрішню поверхню патронника, що має різні нерівності (рисунок 6) або під час контакту з краями казенного зрізу ствола, що має (внаслідок грубої обробки) гострі виступи (задири).

Під час визначення конструктивних особливостей зброї, крім зазначених слідів, важливе значення мають і сліди, залишені під час контакту гільзи з іншими деталями і вузлами, що вказують на саморобний спосіб виготовлення зброї. Наприклад, під час загвинчування ствола 3 корпусом саморобних стріляючих пристроїв «авторучок» на денцях гільз від малокаліберного (5,6 мм) патрона можуть залишитися дугоподібні статичні сліди [3, с. 198-205]. Сліди на денцях гільз можуть залишитися також від рамок саморобних револьверів. Вертикальний слід «подряпина» утворюється під час застосування однозарядних пістолетів з переломним стволом, у якого бойок виступає за межі поверхні чашки затвора тощо.

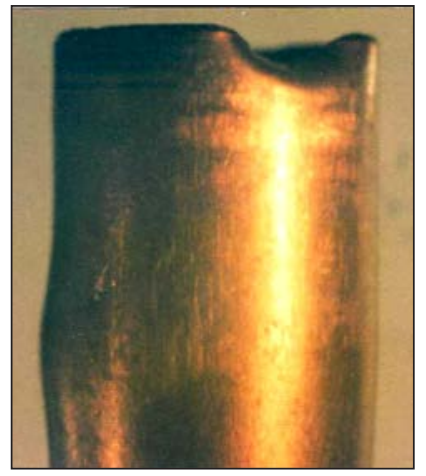

Рис. 5. Слід у вигляді вм'ятини на дульці гільзи (патрон 9х18 мм), що відобразився при ії зажимі між патронним утиком затвора і казенною частиною ствола саморобної вогнепальної зброї

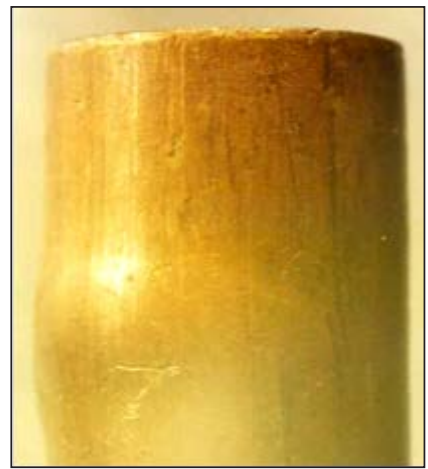

Рис. 6. Гільза від патрона 9x18 мм, стріляна із саморобної вогнепальної зброї. На корпусі гільзи видно поздовжні траси, що відобразилися від дефектів поверхні патронника i виступів-задирок на краї казенного зрізу ствола
До слідів на стріляних гільзах із саморобної вогнепальної зброї також можна віднести:

- вм'ятини і траси на зовнішній межі ребер дулець гільз, утворені за різкого досилання патрона в патронник, які мають нерівну поверхню [4, с. 422-424];

- збільшення або зменшення розміру сліду від бойка;

- нестандартність форми i розташування сліду бойка (рисунок 7) [5, с. 52];

- невідповідна кількість слідів від бойка (рисунок 8);

- наплив металу на капсулі гільзи, розташований навколо сліду бойка, що відображає нерівності передньої грані ударника (за формою, розміром і розташуванням) [6, с. 91-92];

- відсутність сліду від країв каналу (отвори) для бойка ударника (наплив на капсулі навколо сліду бойка). У разі використання 


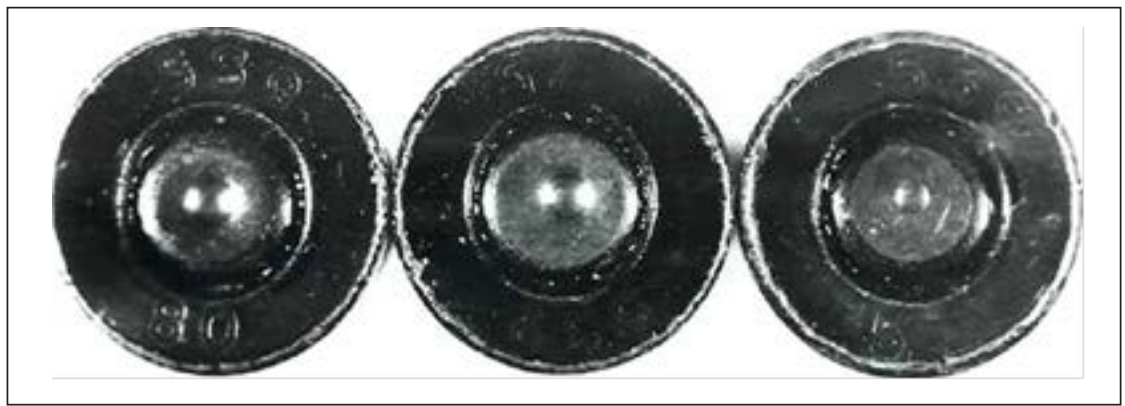

Рис. 7. Сліди від бойка ударника на капсулях гільз 5.45х39 мм, стріляних із саморобної зброї (на фото видно різницю в розташуванні і формі слідів)

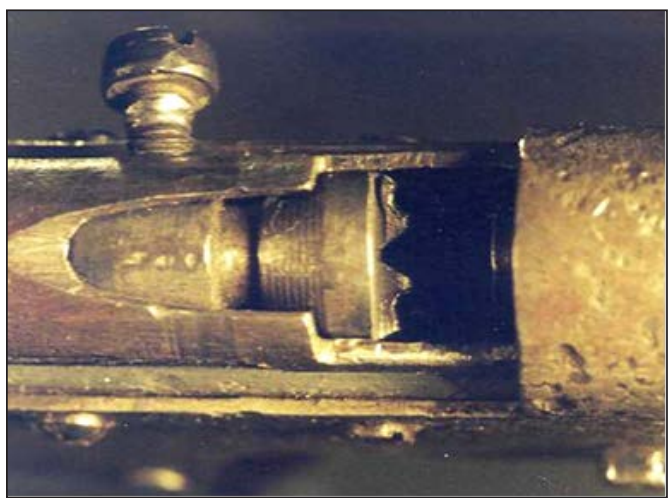

Рис. 8. Два бойка ударника в саморобному пістолеті, призначеному для стрільби малокаліберними патронами 5,6 мм

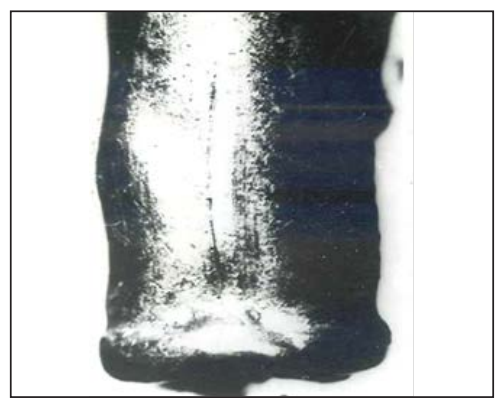

Рис. 9. Сліди здуття гільзи з незначно вигнутим корпусом, утворені під час відстрілу із саморобної зброї з нещільно закритим каналом стовбура

аналогічного патрона, частиною якого є досліджувана гільза, в штатній зброї такий слід повинен відобразитися;

- наявність на капсулях стріляних по черзі гільз різних за розмірами і ступенем виразу слідів осічки. Також спостерігається в зброї, що має дефекти ударно-спускового механізму, викликані саморобною підгонкою деталей;

- наявність на капсулі подвійного, потрійного і навіть зчетверинного сліду бойка або його сліду у вигляді суцільного розплющеного денця гільзи [7, с. 14];

- здуття корпусу гільзи біля денця з незначною витягнутостю і нахилом останньої; що вказує на застосування саморобної вогнепальної зброї з нещільно замикаючим каналом ствола (рисунок 9) [8, с. 41];

- опуклість денця гільзи і деформація ії дульца в результаті повернення вперед ударної системи після пострілу в разі повного виходу гільзи з патронника під тиском порохових газів. Зазначена деформація також зумовлена неповним замиканням каналу ствола через малу масу ударної системи і відсутністю екстрагуючого механізму;

- видавлювання капсуля з гнізда або його повне викидання свідчить про значне виступання за межі казенного зрізу патронника корпуса гільзи або про нещільне його замикання (рисунок 10);

- численні вм'ятини на гранях фланців гільз, що утворилися через невідповідність останніх формою і розмірами чашечки затвора [9, с. 77-82];

- численні вм'ятини на денці гільзи, які утворюються через дефекти поверхні патронного утику (фото 11); 


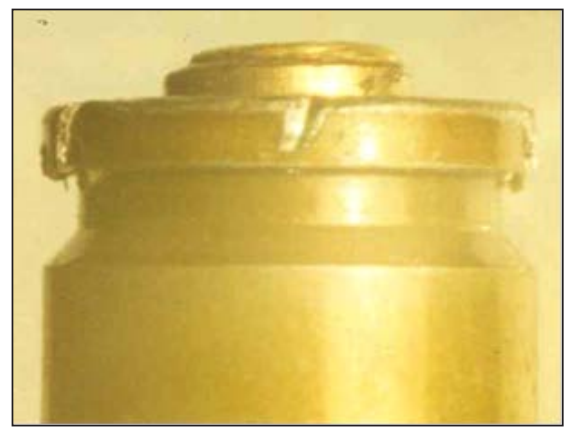

Рис. 10. Гільза патрона 5,45x39 зі зміщеним (видавленим) капсулем, стріляна із саморобної зброї

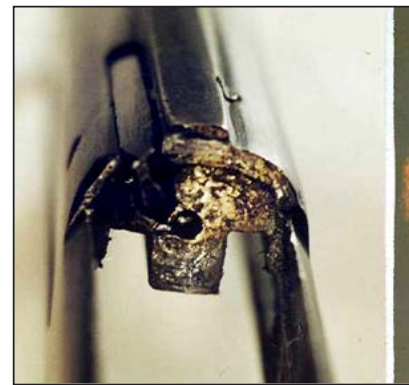

a)

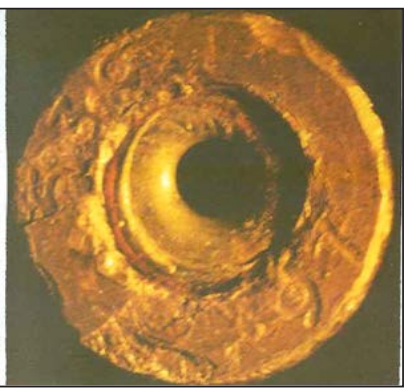

б)
Рис. 11. а) Частина затвора саморобного пістолета з дефектами поверхні патронного утику; б) денце гільзи патрона 9х18, стріляної в саморобному пістолеті (на поверхні гільзи видно вм'ятини)

- нестандартність форми, розміру і локалізації слідів зачіпу викидача, відбивача або відсутність цих слідів. Значення описаних ознак для встановлення виду зброї неоднакове, вони можуть слугувати підставою для висновку лише в певній сукупності;

- сліди у вигляді подряпин і вм’ятин на внутрішній поверхні, утворені в результаті ручного вилучення гільзи з патронника за допомогою шомпола або іншого предмета, що його замінює;

- наявність на поверхні гільз слідів суцільного або локального (у верхній третині) окопчення. Поява окопченням пояснюється похибками в саморобній технології виготовлення ствола, а також дефектами замикання патронника зброї затвором внаслідок некваліфікованої підгонки деталей зброї.

Наявність будь-якої ознаки, зазначеної в переліку, особливо в поєднанні з іншими ознаками, не тільки свідчить про застосування зброї саморобного виготовлення, а й може сприяти визначенню її конструктивних особливостей.

\section{Список використаних джерел:}

1. Зайцев В.Ф., Степанов Г.Н. Определение примененного огнестрельного оружия, переделанного из современных образцов газо-шумового, по его следам на гильзах, пулях и преградах. Экспертиза на службе следствия. Волгоград, 1998. С. 97-99.

2. Устинов А.И., Филиппов В.В. Влияние некоторых особенностей самодельного оружия на образование следов на стреляных гильзах. Экспертная практика. Москва, 1966. Сб. 1. С. 81-85.

3. Григорьев Л.И. Криминалистическое исследование самопалов-«авторучек». Советская криминалистика на службе следствия. Москва, 1961. Вып. 14. С. 198-205.

4. Прищепа В.М. Отождествление оружия по редко встречающимся следам на гильзах. Криминалистика и судебная экспертиза. Киев, 1972. Вып. 9. С. 422-424.

5. Русаков М.Н. Криминалистическое исследование оружия и следов его применения. Омск, 1981. С. 52.

6. Ицков В.И. Идентификации оружия по следам видоизмененного канала ствола. Экспертная практика. Москва, 1966. Сб. 1. С. 91-92.

7. Криминалистическое исследование следов бойка при осечке, последующем выстреле и повторных ударах бойком по капсюлю гильзы (методические рекомендации). Москва, 1977. С. 14.

8. Демин Н.С. Пистолет для подводной охоты как объект судебно-баллистического исследования. Экспертная техника. Москва, 1974. Вып. 34. С. 41.

9. Максименков А.А., Карпов А.К., Посада Х.А., Рощин И.В. Следы выстрела рассказывают о факте переделки оружия. Экспертная практика. Москва, 1990. № 29. С. 77-82. 